\title{
SFERA PUBLICZNA TRWALE WARUNKOWANA. STUDIUM PRZYPADKU POWIATOWEJ DEBATY PUBLICZNEJ W UJĘCIU MORFOGENTYCZNYM
}

\section{Streszczenie}

W artykule zanalizowano uwarunkowania morfogenetyczne funkcjonowania lokalnej sfery publicznej. Wskazano bariery jej rozwoju w kontekście istniejących w Polsce emergentnych struktur społecznych (interesy) oraz kulturowych (idee, wartości). Kontekst ten cechuje się dominacją kulturową, społeczną i ekonomiczną jednej warstwy - inteligencji. Na podstawie założeń ontologicznych i epistemologicznych teorii morfogenezy przedstawiono studium przypadku debaty publicznej w Tarnowskich Górach. Analizie jakościowej poddano dane terenowe (obserwacja uczestnicząca), wykorzystując elementy krytycznej analizy dyskursu oraz założenia idealnej sytuacji komunikacyjnej Jürgena Habermasa.

Słowa kluczowe: sfera publiczna, obserwacja uczestnicząca, wzory aktywnego obywatelstwa, morfostaza, zbiorowe podmioty działania

\section{WPROWADZENIE}

Dla socjologii życia publicznego istotnym obszarem badań jest sfera publiczna ${ }^{1}$ stanowiąca miejsce uzgadniania roszczeń między konkurencyjnymi wartościa-

* Dr, Katedra Stosowanych Nauk Społecznych, Wydział Organizacji i Zarządzania; e-mail: p.werynski@interia.pl

1 Wskazać można pięć fundamentalnych sposobów konceptualizowania sfery publicznej, które przekładają się na dominujące współcześnie dyskursy ideologiczne i społeczno-polityczne. W niedosłownym nawiązaniu do typologii dominujących koncepcji sfery publicznej Seyli Benhabib [1992] wyróżnić można: (1) odwołujący się jeszcze do starogreckich koncepcji polis i cnót obywa- 
mi, interesami i ideologiami [Wnuk-Lipiński 2008: 178-189]. W tym artykule przyjmuje się szerokie rozumienie sfery publicznej - jako przestrzeni dyskursu społecznego, kontestacji oraz wypracowania zmiany (morfogenezy) lub reprodukcji (morfostazy) elementów sytemu społecznego i kulturowego, w ramach którego tworzy się konsens ideacyjny oraz instytucjonalny.

Stan współczesnej polskiej sfery publicznej niewiele odbiega od klasycznej diagnozy zachodnich sfer publicznych Jürgena Habermasa [2007]. Zauważalne jest skolonializowanie życia publicznego przez powiązane z głównymi partiami politycznymi media, w których odbiorców przekazów medialnych traktuje się jak pozbawionych indywidualnych preferencji klientów, poddaje się ich manipulacji, używając socjotechnik nacechowanych emocjonalnością. Jednak w polskiej sferze publicznej można odnaleźć unikatowe elementy socjo-kulturowe oraz strukturalne, które ogniskują się wokół wzorów aktywności obywatelskiej kluczowej, choć wewnętrznie ideowo i ekonomicznie zróżnicowanej, warstwy społecznej - inteligencji. W hybrydowy sposób pojmowana inteligencja to niejednorodna, ukształtowana w końcu XIX i pierwszej połowie XX wieku, warstwa społeczna. Tworzą ją ludzie w zdecydowanej większości legitymujący się wykształceniem wyższym, przy czym warunek posiadania wyższego wykształcenia jest zwykle konieczny, ale niewystarczający, ma dominujące znaczenie w sferze edukacji, kultury, medycyny, administracji, sfery publicznej oraz zarządzania gospodarką [Bartoszek 2003]. Współcześnie w sferze wyznawanych zasad aksjonormatywnych i ideologii obywatelskich członkowie tej warstwy odwołują się do dwóch głównych, często sprzecznych, wzorów: po pierwsze, do tradycyjnie pojmowanego inteligenckiego etosu [Libelt 1967: 61; Znaniecki 1990: 44-45], bliskiego republikańskiej ideologii partycypacji obywatelskiej; po drugie, do mieszczańskich oraz liberalnych wzorów uczestnictwa w życiu społecznym. Wzory liberalne realizują głównie grupy społeczno-zawodowe identyfikujące się z nową klasą średnią [Kurczewska 1998: 337-343; Domański 2008], charakterystyczną dla rozwiniętych, postkapitalistycznych społeczeństw zachodnich.

telskich - nurt republikański (Hannah Arendt), (2) współcześnie ciągle istotny narracyjnie - nurt liberalny (Ronald Dworkin), (3) socjalliberalny, utożsamiany z deliberatywną sferą publiczną(Jürgen Habermas), (4) popularny przede wszystkim w USA - nurt komunitarystyczny (np. Michael Walzer) oraz (5) nurt postmarksowski, radykalnie krytyczny wobec istniejących form kapitalizmu, liberalnej demokracji oraz wobec stanowiącej ich dopełnienie sfery publicznej, utrwalającej istniejący układ klasowy (np. Ernesto Laclau). Ujęcie morfogenetyczne sfery publicznej, uwzględniające wzajemną relację między strukturą a sprawstwem, dystansuje się od głównych sporów ideologicznych, a tym samym różni się od dominujących, nacechowanych normatywnie koncepcji. 
Wspomniana unikatowa właściwość klasowo-warstwowa w dużej mierze warunkuje funkcjonowanie polskiej sfery publicznej, narzuca dwie opozycyjne narracje obywatelskie. Dwa wzory uczestnictwa w życiu publicznym odciskają swoje piętno również na regionalnych i lokalnych dyskursach publicznych. Są kulturowym i ideologicznym źródłem barier komunikacyjnych, podziałów społecznych, a w konsekwencji morfostazy społecznej. Stąd teza o polskiej sferze publicznej jako przestrzeni trwałego podtrzymywania morfostazy (reprodukcji) istniejącego porządku stratyfikacyjnego, ściślej: inteligenckiej dominacji na każdym (w tym lokalnym) poziomie życia społeczno-ekonomicznego.

W artykule dokonana zostanie analiza uwarunkowań funkcjonowania lokalnej sfery publicznej w kontekście istniejących w Polsce emergentnych własności strukturalnych - grupowych interesów oraz w szczególności własności kulturowych - idei i wartości legitymizujących interesy [Archer 2013: 269-283]. Kluczowe pytanie badawcze, na które autor będzie szukał odpowiedzi, brzmi: czy w postawach uczestników lokalnej (Tarnowskie Góry) debaty publicznej odzwierciedlają się elementy składowe dwóch dominujących emergentnych własności kulturowych warunkujących ogólnopolskie wzory aktywnego obywatelstwa? Istotne poznawczo będzie również znalezienie odpowiedzi na dwa uzupełniające pytania badawcze, które dotyczyć będą odpowiednio struktury podmiotowej oraz przedmiotowej badanej debaty: (1) czy i w jakim zakresie relacje między określonymi nadawcami, pośrednikami i odbiorcami komunikatów, stanowiących treści badanej debaty, mogą być analizowane poprzez odniesienie ich do idealnotypicznych założeń sytuacji komunikacyjnej Habermasa; (2) które elementy wyróżnionych wzorów aktywności obywatelskiej (zworniki tematyczne) dominują wśród uwarunkowań kulturowych kształtujących formę i treść badanej debaty?

\section{SFERA PUBLICZNA W UJĘCIU MORFOGENTYCZNYM}

Stan sfery publicznej oraz instytucji społeczeństwa obywatelskiego jest wyrazem sprawczości rzeczywistych zbiorowych podmiotów działania posiadających określone interesy grupowe i legitymizujące je systemy aksjonormatywne. Szansę na dokonanie analizy funkcjonowania określonej sfery publicznej stwarza odwołanie się do kategorii pojęciowych teorii morfogenetycznej dotyczących społecznego sprawstwa - pierwotnych i zbiorowych podmiotów działania, emergentnych właściwości strukturalnych i kulturowych oraz interakcji między sprawstwem a strukturą [Archer 1996; 2013: 254-283; Bhaskar 1998b]. Ujęcie morfogenetyczne różni się od dominujących koncepcji sfery publicznej przyjmo- 
waną ontologiczną równoważnością kategorii struktury (instytucji) i sprawstwa, koncentracją na diagnozie, poszukiwaniu przyczyn istniejących uwarunkowań społeczno-kulturowych, nie zaś wskazywaniu wzorców normatywnych. W powyższym ujęciu funkcjonowanie sfery publicznej oraz instytucji społeczeństwa obywatelskiego w dużej mierze zależy od sprawczości zbiorowych podmiotów działania. Archerowska koncepcja sprawstwa jest przydatna w badaniach nad podmiotami działania w sferze publicznej ze względu na możliwość analitycznego odróżnienia tego, co strukturalne, od tego, co jest efektem podmiotowych działań dominujących aktorów społecznych. Pozwala na określenie marginesu wolności dla działań jednostek oraz zakresu ich ograniczeń wynikających z uwarunkowań instytucjonalnych [Archer 1985: 82; 2013: LX]. Zastane struktury społeczne oraz systemy kulturowe warunkują (ale nie determinują) interakcję społeczną, której efektem jest reprodukcja lub transformacja tych struktur w kolejnych fazach cyklu morfogenetycznego: społecznego oraz kulturowego warunkowania, interakcji oraz przepracowania.

W teorii morfogenezy występuje analityczne wyodrębnienie dwóch rodzajów zjawisk kulturowych, w obrębie których dochodzi do konfrontacji opozycyjnych systemów aksjonormatywnych, a w sferze publicznej - opozycyjnych wzorów aktywnego obywatelstwa. Istnieje system kulturowy, który obejmuje idee pozostające ze sobą w logicznych relacjach sprzeczności i uzupełniania się. Zachodzą także interakcje społeczno-kulturowe, które dotyczą, w zależności od konfiguracji elementów systemu kulturowego, konfliktowych lub uporządkowanych relacji między jednostkami i grupami interesu. $\mathrm{W}$ ich ramach indywidualne $\mathrm{i}$ grupowe podmioty działania odwołują się do idei pochodzących z systemu kulturowego, aby realizować swoje interesy materialne i idealne [Archer 1996]. Dominujące w danym systemie strukturalno-kulturowym emergentne właściwości kulturowe (zespół kluczowych idei) warunkują proces morfogenezy lub morfostazy sfery publicznej.

Przemiany wzorów uczestnictwa w sferze publicznej, osadzone w historycznie uwarunkowanej strukturze społeczno-kulturowej, oraz konieczność uwzględniania indywidualnego i grupowego sprawstwa dla ich przemiany, wydają się szczególnie predysponowane do morfogentycznej analizy. Dlatego można postawić tezę, że przyczyn obecnego stanu polskiej sfery publicznej należy szukać w historycznie ukształtowanym systemie emergentnych właściwości strukturalnych (EWS) i kulturowych (EWK). Wyraża się on, w wymiarze EWS, dominującą rolą jednej warstwy społecznej - inteligencji. Dominacja ta występuje w zakresie trzech głównych właściwości strukturalnych: władzy, posiadania i prestiżu. Własności strukturalne tworzy system relacji między dwoma inteligenckimi elitami, posiadającymi swoje reprezentacje polityczne, wraz 
z powiązanymi z nimi grupami społeczno-zawodowymi. Realizują, zbliżony do Paretowskiego, mechanizm krążenia elit, jednak żadna $\mathrm{z}$ nich ostatecznie nie kończy na cmentarzysku historii. Reprezentują odrębne, często sprzeczne interesy materialne. Przejawiają się one istnieniem napięć strukturalnych na linii etatystyczna-deregulacyjna polityka gospodarcza. Różnią się stosunkiem do preferowanego systemu podatkowego, realizowanej polityki oświatowej, obowiązującego modelu edukacji i szkolnictwa wyższego, polityki kulturalnej i historycznej, skali integracji europejskiej, sposobów rozwiązywania problemów imigracyjnych czy skali prywatyzacji służby zdrowia. Uczestniczą w ciagłym tworzeniu logik sytuacyjnych, w ramach których toczy się walka o władzę na poszczególnych poziomach życia politycznego (lokalnego, regionalnego, ogólnokrajowego).

Natomiast w sferze publicznej inteligencja występuje jako główny kreator dwóch wzorów aktywności obywatelskiej (tradycyjnie etosowego i mieszczańskiego). Wspomniane uwarunkowania strukturalne są legitymizowane przez dominujące EWK, czyli zespół założeń aksjonormatywnych powiązanych odpowiednio z ideologią republikańską oraz liberalną. Tworzące system społeczny dominujące EWS i EWK stwarzają warunki do realizacji interesów i wartości uprzywilejowanej części społeczeństwa - inteligenckiego metauniversum [Zarycki, Warczok 2014]. Inteligencja zdominowała dyskursy publiczne, spetryfikowała zarówno ich struktury podmiotowe (rodzaj uczestników), jak i przedmiotowe (zakresy tematyczne) na poziomie krajowym, regionalnym i lokalnym, narzucając własne narracje ideologiczne, tym samym marginalizując znaczenie idei i narracji odmiennych.

W prezentowanych badaniach terenowych analiza podmiotowa skupiać się będzie głównie na, po Archerowsku rozumianych, zbiorowych podmiotach działania. Biorą one aktywny udział w procesie reprodukcji lub transformacji systemu społecznego i kulturowego. Obejmuja grupy świadome swoich interesów (utrwalonych lub promowanych), ruchy, zrzeszenia realizujące w obrębie struktury i kultury swoje strategiczne cele. W kontekście prezentowanych badań nad wzorami aktywności obywatelskiej zbiorowymi podmiotami działania będą przedstawiciele administracji samorządowej, organizacji politycznych, biznesowych, społeczno-zawodowych, organizacji pozarządowych non-profit (w sensie klasowo-warstwowym głównie inteligencja i nowa klasa średnia) stanowiące zaplecze społeczne dla realizacji zespołu interesów grupowych oraz idei republikańskiej i liberalnej.

Archer wyróżnia również pierwotne podmioty działania, które „nie mają prawa głosu w procesie przekształcania struktury i kultury. Nie wyrażają one inte- 
resów, ani nie organizują się po to, by zrealizować strategiczne cele" w wymiarze społecznym, gospodarczym czy politycznym [2013: 265-266]. Do tej kategorii społecznej zaliczyć można jednostki ze środowisk biernych obywatelsko, często też wykluczone lub bliskie wykluczenia społecznego, ekonomicznego, nieuczestniczące w życiu społeczno-kulturalnym swoich społeczności lokalnych, które pozostają poza grą interesów i idei między głównymi podmiotami badanego systemu kulturowego (np. prekariat).

\section{PODSTAWY METODOLOGICZNE ANALIZY WYBRANEJ DEBATY PUBLICZNEJ}

W konceptualizacji badań nad partycypacją zbiorowych podmiotów działania w sferze publicznej pomocne również będzie, wywodzące się z emergentnego strukturalizmu socjologicznego, ontologiczne założenie o emergentnych poziomach rzeczywistości społecznej. Jeżeli odwołamy się do realizmu socjologicznego Pawła Rybickiego [1979: 56-57] oraz nawiązujących do niego założeń ontologicznych emergentnego strukturalizmu Jacka Szmatki [1989: 13-26] - dotyczącego statusu społecznych bytów ponadjednostkowych cechujących się nieciagłością własności, jakościową odrębnością i wewnętrzną jednorodnością - to będzie można skonstatować, że tworzą nieredukowalne do siebie, ale też wzajemnie się warunkujące poziomy rzeczywistości. Tak rozumiana emergencja poziomów społecznych ${ }^{2}$ zarówno działających jednostek, które posiadają potencjał sprawstwa wynikający z ich refleksyjności, jak i bardziej złożonych form społecznych z poziomu mikro-, mezo-, makrospołecznego, pozwala traktować zjawiska i procesy społeczne występujące na każdym z poziomów jako osobne przedmioty badań. Ma to istotne poznawczo znaczenie, ponieważ złożone zjawiska czy procesy społeczne występują zwykle na kilku poziomach integracji życia społecznego, ich wyodrębnienie na każdym z interesujących badacza poziomów umożliwia dobranie metody badawczej na danym poziomie emergentnej rzeczywistości.

Proponowanym sposobem badania relacji między emergentnymi poziomami rzeczywistości jest triangulacja poziomów analizy, czyli uwzględnianie wzajemnego oddziaływania elementów mikro, mezo i makro rzeczywistości. Dużą rolę

2 Założenie o emergencji poziomów społecznych jest niesprzeczne z teorią morfogenetyczną i realizmem krytycznym, bo mechanizmy generatywne wynikające z relacji struktura-sprawstwo działają na wszystkich poziomach rzeczywistości społecznej - mikro, mezo i makro, patrz casus analiz systemów edukacyjnych [Archer 2015: 10-11]. 
przy tym podejściu odgrywają oddziaływania emergentnych sił przyczynowych na każdym poziomie, które można traktować jako wyraz interakcji społeczno-kulturowych między działaniami struktur a sprawstwem zbiorowych podmiotów działania. Istotne są relacje, sprzężenia zwrotne między dyskursami centralnej sfery publicznej a jej regionalnymi i lokalnymi odpowiednikami.

W analizie działania uwarunkowanych strukturalnie i kulturowo emergentnych sił przyczynowych, które występuje na wszystkich poziomach życia społecznego, przydatne było stosowanie triangulacji metod: jakościowych, ilościowych oraz analizy danych zastanych. Wykorzystano dwie metody jakościowe: metodę badań terenowych połączoną z obserwacją uczestniczącą oraz elementy krytycznej analizy dyskursu (CDA). W ramach triangulacyjnej procedury badawczej dane $\mathrm{z}$ badań jakościowych, dotyczące występowania w wybranej debacie publicznej elementów (zworników tematycznych) dwóch wzorów aktywnego obywatelstwa, były konfrontowane z reprezentatywnymi w sensie statystycznym wynikami badań sondażowych CBOS. Ich zakresy tematyczne (opinie Polaków o kluczowych cechach demokracji) relatywnie często pokrywały się ze zwornikami tematycznymi identyfikowanymi w badaniach jakościowych.

TABELA 1. Dominujące polskie wzory aktywnego obywatelstwa

\begin{tabular}{|c|c|c|}
\hline & \multicolumn{2}{|c|}{ Zworniki tematyczne do kategoryzacji wypowiedzi uczestników debaty } \\
\hline & Republikański (R) & Liberalny (L) \\
\hline $\begin{array}{l}\text { 1. Rozumienie } \\
\text { wolności }\end{array}$ & $\begin{array}{l}\text { „wolność do”, czyli obowiązek uczest- } \\
\text { nictwa }\end{array}$ & $\begin{array}{l}\text { „wolność od”, rozumiana jako prawo } \\
\text { do nieuczestnictwa }\end{array}$ \\
\hline $\begin{array}{l}\text { 2. Typ działań } \\
\text { społecznych }\end{array}$ & $\begin{array}{l}\text { wspólnotowość - } \\
\text { zoon-politikon przedkłada potrzeby } \\
\text { wspólnoty nad indywidualną samore- } \\
\text { alizację; jednostka może się spełniać, } \\
\text { gdy ma prawo do udziału w urzeczy- } \\
\text { wistnianiu dobra wspólnego }\end{array}$ & $\begin{array}{l}\text { indywidualizm - } \\
\text { homo oeconomicus - najwyższym do- } \\
\text { brem jest szczéście i realizacja potrzeb } \\
\text { jednostki, kolektyw jeżeli ma wartość, } \\
\text { to tylko w kontekście urzeczywistnia- } \\
\text { nia praw indywidualnych }\end{array}$ \\
\hline 3. Cele & poczucie misji, prymat idei & pragmatyzm, prymat interesu \\
\hline $\begin{array}{l}\text { 4. Stosunek } \\
\text { do kapitalizmu }\end{array}$ & pogarda dla dorabiania się & aprobata dla przedsiębiorczości \\
\hline $\begin{array}{l}\text { 5. Typ } \\
\text { uczestnictwa } \\
\text { w kulturze }\end{array}$ & $\begin{array}{l}\text { jako wartość autoteliczna potrzeby } \\
\text { poznawcze, estetyczne }\end{array}$ & $\begin{array}{l}\text { wartość instrumentalna wobec celów } \\
\text { zawodowych, prestiżowych }\end{array}$ \\
\hline $\begin{array}{l}\text { 6. Pojmowanie } \\
\text { czasu }\end{array}$ & $\begin{array}{l}\text { retrospektywne (szacunek wobec } \\
\text { przeszłości, kultywowanie tradycji) }\end{array}$ & prospektywne (planowanie przyszłości) \\
\hline \begin{tabular}{|l} 
7. Typ aktywno- \\
ści społecznej
\end{tabular} & $\begin{array}{l}\text { patronacki, protekcjonalny wobec } \\
\text { innych warstw społecznych }\end{array}$ & $\begin{array}{l}\text { partnerski, zorientowany na koopera- } \\
\text { cję, współdziałanie }\end{array}$ \\
\hline
\end{tabular}




\begin{tabular}{|l|l|l|}
\cline { 2 - 3 } \multicolumn{1}{c|}{} & \multicolumn{2}{c|}{ Zworniki tematyczne do kategoryzacji wypowiedzi uczestników debaty } \\
\cline { 2 - 3 } \multicolumn{1}{c|}{} & \multicolumn{1}{c|}{ Republikański (R) } & \multicolumn{1}{c|}{ Liberalny (L) } \\
\hline $\begin{array}{l}\text { 8. Stosunek } \\
\text { do państwa }\end{array}$ & $\begin{array}{l}\text { etatyzm, interwencjonizm, centralizm, } \\
\text { ograniczone zaufanie do spontanicz- } \\
\text { nych działań społecznych }\end{array}$ & $\begin{array}{l}\text { antyetatyzm, decentralizacja, dere- } \\
\text { gulacja }\end{array}$ \\
\hline $\begin{array}{l}\text { 9. Stosunek } \\
\text { do prawa }\end{array}$ & $\begin{array}{l}\text { punitywny, rygoryzm prawny, podkre- } \\
\text { ślanie wagi regulacji prawnych }\end{array}$ & $\begin{array}{l}\text { permisywny, akceptacja zasady: co nie } \\
\text { jest zabronione, jest dozwolone }\end{array}$ \\
\hline
\end{tabular}

Źródło: opracowanie własne ${ }^{3}$.

W konstrukcji powyższej typologii dwóch wzorów aktywnego obywatelstwa wykorzystano, obok badań własnych elit lokalnych [Weryński 2008; 2010], rezultaty badań nad stylami życia inteligencji polskiej Hanny Palskiej [2007]. Tworzą one kluczowe zworniki tematyczne analiz interakcji w sferze publicznej (idee republikańskie versus idee liberalne). Wzory aktywnego obywatelstwa oraz odpowiadające im główne zworniki tematyczne odnajdywane w debacie (wątki kategoryzujące opinie badanych) stanowiły podstawę scenariusza obserwacji uczestniczącej. Jednak nie należy utożsamiać ich z programami politycznymi wiodących w Polsce partii, a raczej z antagonistycznymi pojęciami wzorcowymi osadzonymi w historycznie ukształtowanej strukturze klasowo-warstwowej, powstającymi w zobiektywizowanych społecznych procesach dhugiego trwania, często wielowiekowych doświadczeń i porównań [Ossowska 1985].

Przejawem stosowania triangulacyjnej procedury badawczej było też odwołanie się do wybranych elementów kolejnej metody jakościowej - badań dyskursywnych. Problematyka życia publicznego i związana z nią aktywność obywatelska mogą być analizowane jako swego rodzaju obszar myślenia dyskursywnego [Czyżewski 2005; 2008], w którym różni aktorzy społeczni podejmują się uzgodnienia często przeciwstawnych aksjologicznie stanowisk. Jürgen Habermas tak rozumie sposób na racjonalne rozstrzyganie sporów ideologicznych oraz aksjologicznych $\mathrm{w}$ obszarze sfery publicznej. $\mathrm{Z}$ teorii działania komunikacyjnego, mimo istotnych ograniczeń normatywnych, wynikają pewne możliwości zastosowań diagnostycznych. Rzeczywiste relacje między nadawcami, pośrednikami oraz odbiorcami komunikatów, stanowiących treści debat publicznych, mogą być rozpatrywane poprzez odniesienie do czterech idealnotypicznych założeń sytuacji komunikacyjnej wprowadzonej przez twórcę

3 Zaprezentowane powyżej zestawienie, ponumerowanych od 1 do 10 i oznaczonych symbolami L (liberalny) lub R (republikański), zworników tematycznych będzie w podrozdziale 5 wykorzystane do kategoryzowania wypowiedzi uczestników, np. zwornik 2L oznacza typ działań społecznych numer 2 przypisany do liberalnego wzoru aktywności obywatelskiej (L). 
Strukturalnych przeobrażeń sfery publicznej. Stąd postawione we wstępie artykułu uzupełniające pytanie badawcze o zakres przydatności wspomnianych założeń do analizy tarnogórskiej debaty.

Wspomniany typ badań dyskursywnych znajduje ukonkretnienie w metodzie częściowo przydatnej w tej pracy ${ }^{4}$ - krytycznej analizie dyskursu (CDA), która za przedmiot swoich analiz wybiera między innymi debaty publiczne [van Dijk 2006: 1042-1045]. CDA traktuje dyskursy jako społeczne formy komunikacji odzwierciedlające realne i doniosłe działania, praktyki społeczne, dotyczące sfery dominacji kulturowej oraz władzy [van Dijk 1993: 254]. Należy uwzględnić w analizie konteksty kulturowe i ideologiczno-polityczne, w których dyskursy mają miejsce, kategorie uczestników, czyli elementy analizy podmiotowej, ich działania społeczne, reguły i strategie dochodzenia do celów uczestników dyskursu. Ponadto $\mathrm{w}$ analogii do istniejących w podejściu dyskursywno-krytycznym opozycyjnych kategorii analitycznych, np. Swój i Obcy [Kopytowska, Kumięga 2017: 197], zanalizować należy odbijające się w języku uczestników dyskursu oraz w jego kontekście społeczno-kulturowym przejawy istnienia dwóch opozycyjnych wzorów uczestnictwa w sferze publicznej (idei legitymizujących) oraz ich powiązania z relacjami klasowo-warstwowymi.

\section{KONTEKSTY INSTYTUCJONALNE I SPOLECZNE ANALIZY TARNOGÓRSKIEJ DEBATY PUBLICZNEJ}

W niniejszym artykule podjęto próbę analizy otwartej debaty publicznej dotyczącej strategii rozwiązywania problemów bezrobocia i wykluczenia społecznego w Tarnowskich Górach - w powiatowym mieście średniej wielkości (61 tys. mieszkańców) usytuowanym w zachodniej części aglomeracji górnośląskiej. Debaty na wspomniany wyżej temat odbywają się od 2005 roku, zwykle co dwa lub trzy lata. Autor artykułu brał w nich udział trzykrotnie w charakterze obserwatora, natomiast w roku 2009 i 2014 wystapił też w roli eksperta. Mimo że autor uczestniczył w debacie w charakterze eksperta, to jego wystapienie w początkowej, wyodrębnionej, eksperckiej części trzygodzinnej debaty nie przeszkodziło $\mathrm{w}$ realizowaniu roli bezstronnego obserwatora, ponieważ przez dwie i pół godziny możliwa była niezakłócona obserwacja uczestnicząca, sporządzanie notatek, przypisywanie poszczególnych wypowiedzi do przygotowanych

4 Dla autora inspirację stanowi nie wersja radykalna CDA, która prowadzi do całościowej zmiany społecznej, ale interpretacja pozwalająca na diagnozę uwarunkowań strukturalnych i kulturowych, interakcji między podmiotami działania, zmiany wybranych praktyk społecznych. 
wcześniej, stanowiących treść scenariusza obserwacji, zworników tematycznych charakteryzujących dwa wzory aktywności obywatelskich.

Przedmiotem analizy będzie debata „Strategia rozwiązywania problemów społecznych na lata 2006-2015 - ocena poziomu wdrażania" z 8 października 2014 roku, która odbyła się w sali sesyjnej starostwa powiatowego, zorganizowana przez Starostwo Powiatowe oraz Powiatowe Centrum Pomocy Społecznej w Tarnowskich Górach. W debacie udział wzięli przedstawiciele władz samorządowych szczebla gminnego, miejskiego oraz powiatowego, ich partnerzy z lokalnych organizacji pozarządowych, w tym wolontariusze, kierownicy z lokalnych ośrodków pomocy społecznej, powiatowego urzędu pracy, komendy powiatowej policji, kilku lokalnych przedsiębiorców oraz niezależny ekspert z Katedry Stosowanych Nauk Społecznych Politechniki Śląskiej. Łącznie w debacie uczestniczyły 23 osoby, głos w dyskusji zabrało 12 osób.

W ramach spotkania poruszono m.in. problematykę społeczną zawartą w Strategii Rozwoju Powiatu Tarnogórskiego do roku 2022, Strategii Rozwiązywania Problemów Społecznych w Powiecie Tarnogórskim na lata 2006-2015 w obszarze zdrowia psychicznego, uzależnień, program aktywizujący osoby niepełnosprawne „Aktywny samorząd”. Ponadto omówiono sytuację na lokalnym rynku pracy, bariery rozwoju NGO-sów i wolontariatu, działania policji w obszarze przeciwdziałania uzależnieniom oraz profilaktyki, jak również stan realizacji projektów dotyczących aktywizacji i integracji mieszkańców powiatu, których źródłem finansowania jest Europejski Fundusz Społeczny.

Przedstawiony wyżej skład podmiotów debaty warunkował jego treść i formę. Analizowaną debatę zdominowali swoimi narracjami inteligenci. W znacznym stopniu dzieliły ich przekonania światopoglądowe, polityczne, gospodarcze oraz reprezentowane opinie o idei dobra wspólnego. Sposób ich argumentacji i przyjmowanych postaw wobec przedmiotu dyskusji pozwolił wyodrębnić elementy wzorów korespondujące $\mathrm{z}$ ideologią republikańską i liberalną.

Analizie podlegały treści wypowiadanych sądów, opinii oraz kontekst społeczny, polityczny, organizacyjny, personalny, w którym były artykułowane, rozpowszechniane, odbierane. Takie pojmowanie wypowiedzi w społecznym kontekście pozwala wydobyć jego intersubiektywne znaczenie dla przebiegu badanego procesu komunikacyjnego [van Dijk 2006; Nijakowski 2009].

Analizę badanej debaty ustrukturalizowano poprzez wydzielenie z jednej strony trzech głównych podmiotowych kategorii analitycznych (struktury podmiotowej): nadawców, media i osoby pośredniczące oraz odbiorców treści dyskursu, z drugiejprzez wskazanie kluczowych tematów dyskursu, które tworza jego zworniki (strukturę przedmiotowa). Punktem odniesienia dla tworzenia tak pojmowanej struktury 
przedmiotowej dyskursu był zespół zestawionych wyżej cech dwóch wzorów aktywnego obywatelstwa i odpowiednich narracji. Pozwalały one porządkować konstytutywne wątki, zworniki tematyczne badanej debaty. Odzwierciedlały treści badanych interakcji społeczno-kulturowych między strukturalnymi i kulturowymi właściwościami systemu społecznego a wybranymi podmiotami działania.

\section{STRUKTURA PODMIOTOWA ANALIZOWANEJ DEBATY}

Badanie wybranej debaty publicznej rozpoczęto od jej struktury podmiotowej. Przeprowadzono analizę porównawczą perspektyw poznawczych badanych podmiotów życia społecznego, związanych z lokalnymi instytucjami samorządowymi, organizacjami pozarządowymi, biznesowymi biorącymi udział w debacie. W sensie operacyjnym sprowadzała się ona do konfrontacji definicji sytuacji, systemów norm i wartości, interesów badanych zbiorowych podmiotów działania. Rozbieżność perspektyw wyznaczała obszary do analizy dysfunkcji czy napięć strukturalnych, takich jak konflikty interesów, obszary tabu lokalnego życia społecznego (np. powiązania ze zjawiskami oligarchizacji instytucji lokalnych).

Relacje między realnymi nadawcami, pośrednikami i odbiorcami komunikatów, stanowiących treści debaty, były rozpatrywane poprzez odniesienie do idealnotypicznych założeń sytuacji komunikacyjnej. Idealna Habermasowska sytuacja komunikacyjna, czyli stan optymalny dla uzyskania konsensu między stronami interakcji, zakłada: po pierwsze, że sfera publiczna ma charakter otwarty, to znaczy że, nikt, kto mógłby wnieść wkład w dyskurs, nie może zostać wykluczony. To założenie zwykle nie bywa spełnione, nie tylko w realiach polskich. Inkluzja wszystkich istotnych uczestników dyskursu nie jest możliwa, choćby dlatego, że nie życzą sobie tego jej główni uczestnicy, świadomie zawężający pole potencjalnej wymiany argumentów do tych, które są przez nich akceptowalne, czy takich, które nie będą stanowić zagrożenia dla ekonomicznego i społeczno-politycznego status quo. Dotyczy to wszystkich liczących się polskich partii politycznych, ale również większości podmiotów sfery publicznej. Nawet sytuacje debat publicznych, powołane dla poznania opinii najszerszych kręgów społecznych, niosą ograniczenia komunikacyjne spowodowane choćby bardzo zróżnicowanymi zasobami kulturowymi, predyspozycjami osobowościowymi, miejscem aktorów w strukturze stratyfikacyjnej (prestiżu, władzy, pieniądza).

W badanym przypadku lokalnej debaty na problemami bezrobocia i wykluczenia społecznego zasada otwartości sfery publicznej została spełniona tylko w ograniczonym zakresie. Obecni byli wszyscy ważni przedstawiciele władz powiatowych oraz podlegające im służby, zdecydowana większość aktywnych 
NGO-sów, natomiast władze miejskie reprezentowane były przez niskiego szczebla urzędników bez większych kompetencji decyzyjnych (w stopniu inspektora). Władza w mieście, pozostająca w rękach siły politycznej opozycyjnej do władz powiatowych, mając świadomość, że realizowana strategia jest tworem ich oponentów, na żadnym z etapów realizacji projektu nie wykazywała nadmiernej aktywności i chęci współpracy.

Po drugie, w modelu idealnym ma miejsce równouprawnienie komunikacyjne: wszyscy mają jednakową szansę wypowiedzenia się w sprawie. To kolejny warunek, który tylko hipotetycznie może być spełniony, nawet w dojrzałych demokracjach. Dostęp do mediów jest ograniczony przez wspomniane procesy kolonializacji sfery publicznej. Dyskurs publiczny, szczególnie medialnie umasowiony, wpływa na standardy postaw i zachowań obywatelskich jego odbiorców, czy szerzej - jego publiczności. Użyta argumentacja, styl zachowań uczestników debaty oddziałuje na ciągłą reinterpretację rzeczywistości społeczno-politycznej, na obowiązujące wzory uczestnictwa obywatelskiego jej odbiorców. Lech Nijakowski twierdzi, że użytkownicy języka czerpią z tak pojętego dyskursu publicznego leksykę, sposoby argumentacji, źródła legitymizacji postaw własnych, szczególnie w sytuacji, gdy nadawcami komunikatów są autorytety, liderzy lokalni. Oni ogniskują wokół siebie i swoich argumentów opinię innych [Nijakowski 2009: 1-2].

Możliwość wypowiedzenia się przez partnerów interakcji w badanym przypadku była ograniczona przez uwarunkowania strukturalne podmiotowe i przedmiotowe. Gospodarze debaty z urzędu powiatowego, mając świadomość siły mediów i ich funkcji kontrolnych, zadbali, aby przedstawicieli lokalnych i regionalnych gazet i innych mediów elektronicznych nie było na sali podczas debaty. Przesłano im tylko krótki komunikat ex post o przebiegu oraz wnioskach końcowych wynikłych z debaty. Tematyka wypowiedzi, struktura przedmiotowa dyskursu, ramy czasowe i kolejność wypowiedzi uczestników (dostosowane do zajmowanego miejsca w hierarchii urzędniczej, pełnionych funkcji publicznych i powiązań partyjnych) były w dużym stopniu regulowane przez prowadzących debatę.

Po trzecie, w idealnej sytuacji komunikacyjnej zakłada się wykluczenie złudzeń, iluzji, uczestnicy muszą mówić to, co myślą. Rzeczywiste dyskursy są dalekie od powyższego wymogu. Z umysłowości ludzkiej trudno jest wyeliminować autostereotypy, kompensacje, mechanizmy obronne. Ludzie często wolą wybierać złudzenia i iluzje, niż konfrontować się z rzeczywistością. Jak ten warunek był realizowany w badanym kontekście społecznym? Obecni na sali obrad aktorzy społeczni, w dużej mierze dobrani przez przedstawicieli urzędu powiatowego, ulegali narracji prawomyślnej wobec celów i strategii działań gospodarzy debaty. 
Głosów opozycyjnych w stosunku do działań władz powiatowych - twórców i realizatorów strategii rozwiązywania lokalnych problemów społecznych, zanotowano kilka. Artykułowały je osoby albo nie powiązane w żaden sposób z instytucjami podległymi powiatowi, jak na przykład wolontariusze-bezdomni, albo też przedstawiciele opozycyjnego środowiska prawicowego powiązanego $\mathrm{z}$ urzędem miasta, nieprzychylnie nastawieni wobec propozycji powiatu. Nasuwał się wniosek: aby mówić spontanicznie w debacie publicznej to, co się myśli, trzeba być poza wszelką instytucjonalną relacją społeczną (casus bezdomnych wolontariuszy - pierwotnych podmiotów działania, którzy mogli w ten sposób wyrazić swoją potencjalną sprawczość, nie będąc uczestnikami mniej lub bardziej uwikłanych w relacje interesy-idee instytucji czy stowarzyszeń).

Po czwarte, nie ma przymusu: komunikacja nie może podlegać restrykcjom, aby lepszy argument nie mógł dojść do głosu i zdecydować o wyniku dyskusji, debaty [Habermas 2004: 38]. W tak pojętym dyskursie każdemu przysługuje prawo do krytyki i odpierania argumentacji innych uczestników oraz tworzenia własnej strategii obrony. Niezależni prowadzący debaty publiczne, przy założeniu, że cieszą się zaufaniem wszystkich uczestników dyskursu, mogą regulować ich przebieg w taki sposób, aby wszystkie stanowiska mogły być w przybliżonym stopniu reprezentowane $w$ jego ramach. Jednak i tak sytuacja ta dotyczyć będzie tylko aktorów dopuszczonych do dyskursu, tzn. mających środki finansowe, odpowiednio wysoki zasób indywidualnego kapitału społecznego czy wpływy polityczne umożliwiające wyartykułowanie swoich argumentów w mediach czy miejscach debaty.

Merytorycznie uzasadnione stanowiska, dotyczące innego rozkładu środków finansowych na „swoje” oraz „obce” organizacje pozarządowe, pomysły inwestycji, przedstawiane przez osoby niezależne, podlegały marginalizacji, często ośmieszaniu. Po każdym tego typu wystąpieniu prezentowano kilka pomysłów popierających strategię rozwiązywania problemów bezrobocia i wykluczenia w powiecie lansowaną przez władzę powiatową. Wystapienia te były wspierane, a w dużej mierze uprawomocniane wypowiedziami urzędników powiatowego urzędu pracy, powiatowych ośrodków pomocy społecznej oraz przedstawicieli komendy powiatowej policji, którzy posługując się prezentacjami multimedialnymi i cytując serie danych statystycznych, uzasadniali tezy starosty. Debata z czasem zmieniała się w wyreżyserowany spektakl, który miał zakończyć się przygotowaną wcześniej deklaracją zgodną z tezami władz. Debata realizowała wymogi formalne konsultacji społecznej, w sensie merytorycznym była wyreżyserowana tak, aby społecznie legitymizować z góry postawioną tezę. 


\section{STRUKTURA PRZEDMIOTOWA ANALIZOWANEJ DEBATY}

Kolejnym krokiem, po analizie struktury podmiotowej badanego dyskursu, będzie odniesienie się do kluczowych treści (zworników tematycznych; patrz tabela 1), czyli do jego struktury przedmiotowej. Znaczenie szczególnie istotnych komunikatów możliwe jest do pełnego odczytania wtedy, gdy umiejscowi się je w kontekście całościowej struktury debaty. W badanym przypadku płaszczyznę przedmiotową stworzą treści dotyczące stosunku badanych do form oraz zakresu uczestniczenia w lokalnej sferze publicznej. Treści te będzie można uznać za wskaźniki obecności odpowiednio republikańskich oraz liberalnych wzorów aktywności obywatelskiej.

W badanym kontekście społeczno-instytucjonalnym można było odnotować wypowiedzi szczególnie istotne dla podjętej problematyki badań. Pełne odczytanie znaczenia ważnych komunikatów możliwe jest wtedy, gdy umiejscowi się je w kontekście całościowej struktury debaty i odpowiednich narracji zbiorowych podmiotów działania. W badanym przypadku płaszczyznę przedmiotową tworzyły treści dotyczące stosunku badanych do form oraz zakresu uczestniczenia w lokalnej sferze publicznej. Były to treści, które można uznać za zworniki tematyczne, a jednocześnie za wskaźniki obecności odpowiednio republikańskich oraz liberalnych wzorów aktywności obywatelskiej.

O kluczowym znaczeniu tych ideologii w konstytuowaniu europejskiej sfery publicznej wspomina Habermas [2005: 314-315]. Według twórcy teorii działania komunikacyjnego w naukach społecznych, ale również w społecznych narracjach, można wyróżnić dwa główne modele aktywnego obywatelstwa.

Liberalny - wyróżnia się indywidualistycznym oraz instrumentalnym rozumieniem roli obywatela, członkostwem w organizacjach, którego podstawą jest pozycja prawna. Charakteryzuje się założeniem, że jednostki pozostają na zewnątrz państwa, reprezentują postawę wolności „od”, to znaczy, że mają wobec niego zobowiązania - udziału w wyborach, płacenia podatków oraz oczekiwania na przykład świadczeń socjalnych, jednak obywatele nie odróżniają się w sposób istotny od ludzi prywatnych, którzy swoje interesy przeciwstawiają aparatowi państwa czy wspólnoty lokalnej. Ponadto reprezentują postawę permisywizmu prawnego. Są zwolennikami deregulacji w gospodarce i wzmacniania organizacji pozarządowych [Weryński 2008].

Liberalny wzór uczestnictwa obywatelskiego prezentowali przedstawiciele władz powiatowych (starosta ideologicznie bliski Platformie Obywatelskiej), większość osób reprezentujących powiązane z nimi organizacje pozarządowe i instytucje powiatowe oraz przedstawiciele lokalnego środowiska biznesowego. 
Bardziej popierano działania indywidualistyczne niż wspólnotowe - poprzez propagowanie idei „dawania wędki bardziej niż ryby”, wzorców przedsiębiorczości, indywidualnych strategii rozwiązywania swoich problemów przez obywateli społeczności lokalnej (zwornik 1L, 2L). Odnotowane sposoby argumentacji, postawy prezentowane przez tę kategorię uczestników debaty wskazywały na przejawy akceptacji horyzontalnych więzi społecznych, szczególnie potrzebnych dla istnienia dojrzałej lokalnej sfery publicznej, budujących lokalne instytucje społeczeństwa obywatelskiego (,powinno się powierzać rozwiązywanie spraw powiatu, problemów społecznych naszym organizacjom pozarządowym [...]; one najlepiej wiedzą jak pomagać ludziom, bo są wśród nich na co dzień").

Można było odnieść wrażenie, że lokalni zwolennicy rozwiązań liberalnych bardziej ufają rozwiązaniom oddolnym, pomysłom lokalnym, wysuwanym przez innych przedstawicieli miejscowych organizacji pozarządowych niż inspiracjom centralnym („,częściej przeszkadzają, niż pomagają, poradziliśmy już sobie wiele razy, to uda się tym razem"). W większości byli świadomi, że zakres koniecznych ingerencji państwa w życie samorządowe szczebla lokalnego czy regionalnego, życie gospodarcze i działania trzeciosektorowe dotyczące na przykład ekonomii społecznej, powinien być ograniczony do minimum (zwornik 8L). Powyższe obserwacje korespondują z wynikami badań ilościowych reprezentatywnych dla populacji ogólnopolskiej [CBOS, 2017]. Z prezentowanej poniżej tabeli dwuzmiennowej, wyciągniętej z pełnej tabeli metryczkowej, można odczytać, że przekazanie przez państwo jak najszerszych kompetencji samorządom i organizacjom społecznym jest akceptowane jako cecha wyróżniająca państwo demokratyczne przez dwie inteligenckie grupy społeczno-zawodowe. Choć należy zaznaczyć, że przedstawiciele biznesowych, technokratycznych oraz administracyjnych zawodów (nowej klasy średniej) w istotny statystycznie sposób różnią się w podkreślaniu wagi działań deregulacyjnych w stosunku do przedstawicieli grup tradycyjnie inteligenckich, utożsamianych w większym stopniu ze wzorem republikańskim. Koherencja powyższych rezultatów badawczych z poziomu mikro, uzyskanych w wyniku obserwacji uczestniczącej, oraz danych ilościowych z poziomu makro, dotyczących postaw dwóch inteligenckich grup społeczno-zawodowych, może świadczyć o realnym społecznie funkcjonowaniu względnie trwałych wzorów aktywności obywatelskiej. Są one przejawem działania na mikro-, mezo- i makropoziomie klasowo-warstwowych sił przyczynowych, skutkujących reprodukcją stratyfikacji społecznej. Stanowią efekt przepracowania między uwarunkowaniami systemowymi (struktura, kultura) a inteligenckim sprawstwem. 
TABELA 2. Dwie inteligenckie grupy społeczno-zawodowe a delegowanie kompetencji samorządom i organizacjom pozarządowym

\begin{tabular}{|c|c|c|c|c|c|c|c|}
\hline & \multicolumn{4}{|c|}{$\begin{array}{l}\text { A co Pan(i) myśli o jeszcze innych zasa- } \\
\text { dach? Czy są one ważne, aby uznać pań- } \\
\text { stwo za demokratyczne czy nieważne? } \\
\text { Przekazanie przez państwo jak najszer- } \\
\text { szych kompetencji samorządom i organi- } \\
\text { zacjom społecznym }\end{array}$} & \multirow{2}{*}{ Ogółem } \\
\hline & & & $\begin{array}{l}\text { Bardzo } \\
\text { ważne dla } \\
\text { uznania } \\
\text { państwa za } \\
\text { demokra- } \\
\text { tyczne }\end{array}$ & $\begin{array}{c}\text { Średnio } \\
\text { ważne }\end{array}$ & $\begin{array}{c}\text { Niezbyt } \\
\text { ważne }\end{array}$ & $\begin{array}{l}\text { To w ogó- } \\
\text { le nie jest } \\
\text { cechą de- } \\
\text { mokracji }\end{array}$ & \\
\hline \multirow{6}{*}{$\begin{array}{l}\text { Do której } \\
\text { z wymie- } \\
\text { nionych } \\
\text { grup zali- } \\
\text { czył(a)by } \\
\text { się Pan(i) } \\
\text { ze względu } \\
\text { na swoją } \\
\text { obecną } \\
\text { sytuację? }\end{array}$} & \multirow{3}{*}{$\begin{array}{l}\text { Dyrektorzy, } \\
\text { prezesi i kadra } \\
\text { kierownicza } \\
\text { przedsiębiorstw, } \\
\text { instytucji oraz } \\
\text { administracji } \\
\text { państwowej } \\
\text { i samorządowej }\end{array}$} & $\mathrm{N}$ & 21 & 11 & & 2 & 33 \\
\hline & & $\% \mathrm{~W} \mathrm{~W}$ & $62,4 \%$ & $32,9 \%$ & & $4,7 \%$ & $100,0 \%$ \\
\hline & & $\% \mathrm{w}^{*} \mathrm{k}$ & $3,7 \%$ & $4,0 \%$ & & $31,4 \%$ & $3,8 \%$ \\
\hline & \multirow{3}{*}{$\begin{array}{l}\text { Zawody twór- } \\
\text { cze i specjaliści } \\
\text { z wyższym } \\
\text { wykształceniem, } \\
\text { inżynierowie, le- } \\
\text { karze, prawnicy, } \\
\text { nauczyciele }\end{array}$} & $\mathrm{N}$ & 38 & 33 & 2 & & 73 \\
\hline & & $\% \mathrm{~W} \mathrm{~W}$ & $51,6 \%$ & $45,4 \%$ & $3,0 \%$ & & $100,0 \%$ \\
\hline & & $\% \mathrm{w} \mathrm{k}$ & $6,7 \%$ & $12,1 \%$ & $7,4 \%$ & & $8,4 \%$ \\
\hline
\end{tabular}

* \% w w: udział procentowy określonej kategorii społeczno-zawodowej w całościowym rozkładzie badanej próby.

Źródło: opracowanie własne na podstawie danych CBOS (istotność asymptotyczna dwustronna przy teście Chi-kwadrat dla badanych zmiennych wynosi 0,04$)$.

Podczas analizowanej debaty lokalnej liberalnie zorientowani dyskutanci postulowali optymalizację (ograniczenie wydatków lub zmianę grupy docelowej pomocy) wydatków na pomoc wykluczonym społecznie, którzy nie rokują szans „wejścia na nowo do społeczeństwa”. Pośrednio wyrażano ideę wolności od ingerencji władz w prywatne życie obywateli, którzy „mogą sami sobie poradzić w sytuacji sprzyjających warunków gospodarczych i instytucjonalnych w powiecie", a działania władz, takie jak inkubator przedsiębiorczości, stosunkowo tanie kredyty dla bezrobotnych rozpoczynających działalność gospodarczą, pomoga 
zainteresowanym w reintegracji społecznej (zwornik 1L, 3L, 4L). Obiektywnie pozytywne parametry sytuacji społeczno-ekonomicznej w powiecie miały uzasadniać takie stanowisko (np. poziom bezrobocia poniżej 8\% odnotowany już w 2014 roku, jeden z najwyższych w województwie współczynnik liczby organizacji pozarządowych na 10 tysięcy mieszkańców, sprawne służby pomocy społecznej współdziałające z NGO-sami).

Również we wspomnianych ogólnopolskich badaniach ilościowych liberalny postulat ograniczania interwencji państwa w życie obywateli znajduje relatywnie większe zrozumienie wśród zbadanych przedstawicieli wyższej kadry kierowniczej przedsiębiorstw, instytucji, administracji państwowej oraz samorządowej niż wśród badanych przedstawicieli zawodów tradycyjnie inteligenckich.

TABELA3. Dwie inteligenckie grupy społeczno-zawodowe a interwencja państwa w życie obywateli

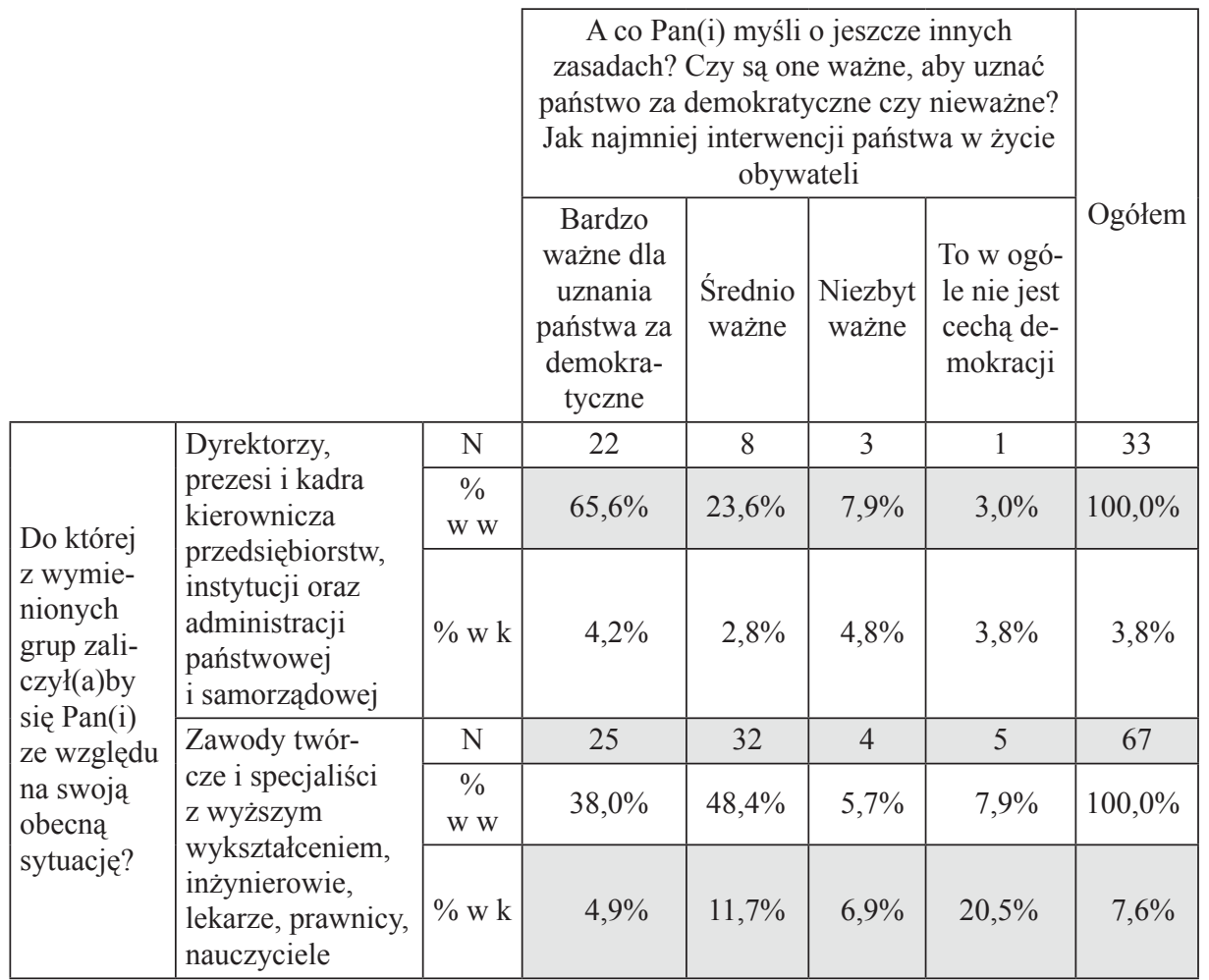

Źródło: opracowanie własne na podstawie danych CBOS (istotność asymptotyczna dwustronna przy teście Chi-kwadrat dla badanych zmiennych wynosi 0,02 ). 
Tak charakteryzowany wzorzec liberalny ma swoje stałe odzwierciedlenie w wymiarze właściwości makrostrukturalnych i wzmacniany jest przez obowiązujące regulacje prawne. Wciąż powszechne liberalne postawy wobec wykluczenia społecznego w skali makro wzmacniane są działaniami ustawodawczymi. Nadal obowiązujący w Polsce system pomocy społecznej wspiera wyżej opisany styl rozwiązywania problemów społecznych i wzór uczestnictwa w życiu publicznym. Wymownym jego wskaźnikiem, ale też przesłanką do jego dalszego trwania, jest obowiązujący w Polsce, jeden z najniższych w Unii Europejskiej, poziom wypłacanych zasiłków dla bezrobotnych w stosunku do średniej płacy (niżej są tylko Bułgarzy). Zmusza on Polaków do skrajnie wolnorynkowych zachowań na rynku pracy. Powszechna strategia realizacji bardziej indywidualnych interesów niż wspólnotowych wartości w sferze publicznej jest dopełnieniem powyższych postaw ekonomicznych [Czapiński, Panek 2015: 314-316].

Genezy drugiego - republikańskiego wzoru aktywności obywatelskiej - należy szukać już u Arystotelesa. Zakłada on komunitarne i etyczne rozumienie roli obywatela, jego przynależność do pewnej samookreślającej się wspólnoty etyczno-kulturowej. Członkowie wspólnoty politycznej są z nią zintegrowani, ich tożsamość osobowa i społeczna może się wykształcić tylko na fundamencie wspólnoty tradycji oraz akceptacji instytucji politycznych, a obywatelstwo wyraża się poprzez działania kolektywne [Petit 1997; Śnieżek 2000: 192]. Tego typu postawy obywatelskie umiejscowić można społecznie wśród przedstawicieli etosowej inteligencji, starej klasy średniej [Gliński 2006: 244-251]. Reprezentują one częściej konserwatywne postawy społeczno-obyczajowe. W polskich realiach republikańsko zorientowane grupy obywateli źródeł swojej tożsamości zbiorowej szukają w narodzie, natomiast reprezentanci idei liberalnych - w państwie.

Republikańskie wzorce uczestnictwa w życiu publicznym można było zaobserwować wśród uczestników debaty wydelegowanych z urzędu miasta, którzy jednocześnie reprezentowali bardziej konserwatywne i prawicowe środowiska zbliżone do Kościoła katolickiego. Ich narracja społeczno-polityczna częściej odwoływała się do wartości wspólnotowych, solidaryzmu społecznego, cnót obywatelskich i obowiązków wobec wspólnoty (narodu, społeczności lokalnej), w dalszej kolejności - wyabstrahowanego bliźniego. Postawy powyższe korespondują $\mathrm{z}$ opiniami zadeklarowanymi przez dwie inteligenckie grupy społeczno-zawodowe (patrz tabela 4) uzyskanymi podczas ilościowych badań CBOS. Przy czym należy podkreślić, że osoby należące do kategorii „zawody twórcze i specjaliści z wyższym wykształceniem, inżynierowie, lekarze, prawnicy, nauczyciele", czyli tradycyjnie pojmowana inteligencja, mocniej wskazywały 
na wymóg aktywności w życiu publicznym, jako bardzo ważną cechę państwa demokratycznego.

TABELA 4. Dwie inteligenckie grupy społeczno-zawodowe a wymóg aktywności w życiu publicznym

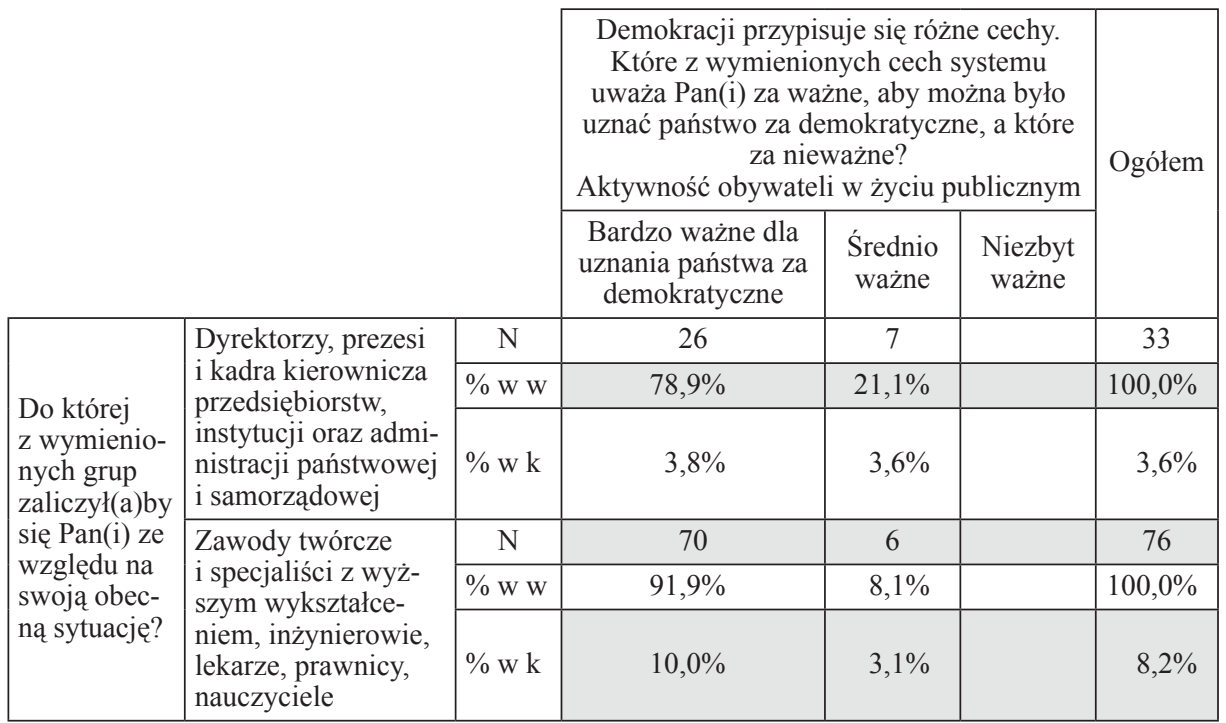

Źródło: opracowanie własne na podstawie danych CBOS (istotność asymptotyczna dwustronna przy teście Chi-kwadrat dla badanych zmiennych wynosi 0,05$)$.

O ile uczestniczy badanej debaty o liberalnej proweniencji ideowej zwracali uwagę na koszty, racjonalność ponoszonych nakładów finansowych i organizacyjnych, o tyle dyskutanci kwalifikowani jako republikanie częściej odwoływali się do poczucia misji społecznej wobec wykluczonych, kształtowania ich postaw i zachowań, realizowania imperatywu miłosierdzia (zwornik 3R). Uczestniczy debaty powiązani z urzędem miasta, a jednocześnie reprezentujący bardziej prawicową, konserwatywną część sceny politycznej powiatu, zdecydowanie częściej odwoływali się do potrzeby działań wspólnotowych, dobra publicznego, ,, dobra powiatu" (zwornik 1R). Należy jednak podkreślić, że postawy te powiązane były z przyzwoleniem na poważną ingerencję w życie wielu środowisk. Charakteryzowały się paternalistycznym stosunkiem do wykluczonych społecznie, bezrobotnych (,trzeba pomagać tym, którzy sobie pomóc nie mogą, bo nikt za nas tego nie zrobi lepiej") (zwornik 7R); ponadto orientacją na wiążący typ kapitału społecznego (podtrzymywanie więzi wspólnotowych), oparty na działaniach grup 
pierwotnych, zakorzenieniu jednostki we wspólnocie lokalnej („w parafii i wśród sąsiadów pomoc społeczna będzie rozprowadzana najefektywniej, nie potrzebujemy u nas obcych organizacji, tym bardziej z Warszawy, jak Owsiak”). Wśród osób, które reprezentowały paternalistyczną postawę wobec lokalnej wspólnoty, gminy, a w pewnym stopniu również powiatu, wymienić należy przedsiębiorcę pochodzącego $\mathrm{z}$ autochtonicznej śląskiej rodziny. W swojej fabryce materiałów budowlanych daje on pracę kilkuset mieszkańcom gminy, ale również, niczym postfeudalny patron troszczący się o ich kondycję moralną, tożsamość lokalna. Osobiście jest zaangażowany w lokalne akcje charytatywne, współtworzy i finansuje monografię na temat ponadsiedemsetletniej historii parafii i gminy (,poczuwam się do obowiązku pomocy gminie i normalnie sprawia mi to przyjemność,... chcę coś po sobie zostawić) (zwornik 6R, 7R).

Działania takich republikańsko zorientowanych aktywistów w sferze publicznej bardziej motywowane były realizacją istniejącej aksjologii („tak wypada katolikowi postępować"), wiarą w autorytety niż indywidualnymi potrzebami samorealizacji społecznej czy potrzebami działań w ramach wolontariatu. Zakres działań i spontanicznych akcji, ,nieprzemyślanych, nieuzgodnionych z powszechnie szanowanymi autorytetami" w powiecie zwolennicy republikańskiego urzędu miasta najchętniej ograniczyliby do minimum (zwornik 8R). To wyznawcy ograniczonego zaufania do poziomych działań społecznych, podkreślający wage regulacji prawnych w życiu społecznym, nawet jeżeli przyjmują one punitywny charakter („,podatki płacimy po to, aby je potem podzielić, a ci, którzy nie płaca, a pracuja, nie zasługują na pomoc ani państwa, ani nikogo innego") (zwornik 9R). Zaprezentowane postawy i opinie pozwalają skonstatować, że przedstawiciele republikańskiego wzoru akceptowali w dużo większym stopniu rolę instytucji państwa jako głównego stymulatora zmiany społecznej w porównaniu z osobami przyjmującymi wzory liberalne, które częściej sprowadzały rolę państwa do minimum, jako „stróża nocnego” oddolnych działań morfogenetycznych.

\section{PODSUMOWANIE}

We wstępie do artykułu postawiono tezę, że polska sfera publiczna jest przestrzenią podtrzymywania inteligenckiej dominacji na wszystkich poziomach życia społecznego. Aby określić specyfikę działania powyższej relacji na podstawie przyjętych założeń teorii morfogenetycznej, dotyczących interakcji między właściwościami strukturalno-kulturowymi a sprawstwem, oraz w oparciu o koncepcje emergentnych poziomów rzeczywistości społecznej, skonstruowano plan badań. Obejmował on badania terenowe z obserwacją uczestniczącą oraz elementy ana- 
lizy dyskursywnej tarnogórskiej debaty publicznej. Ponadto, aby zaprezentować przejawy działania w mikro-, mezo- i makroskali klasowo-warstwowych sił przyczynowych skutkujących reprodukcją stratyfikacji społecznej, zestawiono ze sobą uzyskane rezultaty badań jakościowych z danymi ilościowymi z poziomu makro.

Przeprowadzona triangulacyjna procedura badawcza pozwala stwierdzić, że zdecydowana większość elementów składowych dwóch dominujących emergentnych własności kulturowych warunkujących polskie wzory aktywnego obywatelstwa oraz odpowiadające im narracje jest obecna w lokalnej sferze publicznej oraz w postawach elit lokalnych. Przejawy ich istnienia odnaleźć można w opiniach, zachowaniach, reakcjach liderów opinii reprezentujących zarówno władze samorządowe, lokalny biznes, jak i organizacje pozarządowe czy środowiska wolontariuszy, inaczej mówiąc, lokalne zbiorowe podmioty działania. Wzory te są trwałym składnikiem emergentnych właściwości kulturowych, warunkujących funkcjonowanie lokalnej sfery publicznej. Ograniczają one artykułowanie idei i wartości odmiennych, które mogłyby służyć jako legitymizacja niszowych obecnie interesów zmarginalizowanych podmiotów działania (np. reprezentowanych w mieście przez środowiska lewicowe, mniejszości etniczne, religijne, organizacje ekologiczne).

Wykazana koherencja jakościowych i ilościowych rezultatów badawczych dotyczących elementów postaw obywatelskich dwóch inteligenckich grup społeczno-zawodowych może świadczyć o realnym społecznie funkcjonowaniu względnie trwałych wzorów aktywności obywatelskiej, które są przejawem działania klasowo-warstwowych sił przyczynowych, skutkujących reprodukcją stratyfikacji społecznej. Stanowią efekt przepracowania między uwarunkowaniami systemowymi (struktura, kultura) a inteligenckim sprawstwem. Dominujące wzory aktywnego obywatelstwa są czynnikami sprzyjającymi morfostazie społeczno-kulturowej, przemocy symbolicznej nad zdominowaną i bierną większością.

Drugim celem przeprowadzenia badań terenowych była analiza struktury podmiotowej debaty, relacji między nadawcami, pośrednikami i odbiorcami komunikatów, poprzez odniesienie ich do idealnotypicznych założeń sytuacji komunikacyjnej Habermasa. Przeprowadzona analiza pozwala na stwierdzenie, że zespół Habermasowskich założeń ma ograniczone zastosowanie diagnostyczne. Jego dwa pierwsze warunki, dotyczące wymogu otwartości oraz równouprawnienia komunikacyjnego uczestników debaty, są w rzeczywistych debatach możliwe do spełnienia tylko w minimalnym zakresie, na poziomie deklaracji. Natomiast dwa kolejne, to jest założenie o wykluczeniu z sytuacji komunikacyjnej złudzeń, 
iluzji oraz o komunikacji, która nie może podlegać restrykcjom, uznać trzeba za skrajnie odległe od sytuacji debaty rzeczywistych ludzi trwale obarczonych resentymentami, stereotypami czy zhierarchizowaniem. Słabością tak pojmowanej deliberatywnej koncepcji sfery publicznej jest jej początkowe założenie normatywne o powszechności konsensualnych postaw „rozumnych podmiotów” w świecie sprzecznych interesów i wartości.

\section{BIBLIOGRAFIA}

Archer Margaret. 1995. Realist social theory: the morphogenetic approach. Cambridge: Cambridge University Press.

Archer Margaret. 1996. Culture and agency. The place of culture in social theory. Cambridge: Cambridge University Press.

Archer Margaret. 2000. Being human: the problem of agency. Cambridge: Cambridge University Press.

Archer Margaret. 2003. Structure, agency and the internal conversation. Cambridge: Cambridge University Press.

Archer Margaret. 2013. Cztowieczeństwo. Problem sprawstwa. Kraków: Zakład Wydawniczy NOMOS.

Archer Margaret. 2015. „Morfogeneza: ramy wyjaśniające realizmu”. Uniwersyteckie Czasopismo Socjologiczne UKSW 10: 16-46.

Bartoszek Adam. 2003. Kapitat spoteczno-kulturowy młodej inteligencji wobec wymogów rynku. Katowice: Wyd. UŚ.

Benhabib Seyla. 1992. Models of public space: Hannah Arendt, the liberal tradition and Jurgen Habermas. W: Habermas and the Public Sphere, C. Calhoun (red.), 89-120. Cambridge, MA: MIT Press.

Bhaskar Roy. 1998a. Philosophy and scientific realism. W: critical realism. Essential readings, M. Archer, R. Bhaskar, A. Collier, T. Lawson, A. Norrie (red.), 16-47. London-New York: Routledge.

Bhaskar Roy. 1998b. Societies. W: Critical realism. Essential readings, M. Archer, R. Bhaskar, A. Collier, T. Lawson, A. Norrie, (red.), 206-249. London-New York: Routledge.

CBOS. 2017. Opinie o demokracji. Komunikat z badań nr 117/2017.

Czapiński Janusz, Panek Tomasz (red.). 2015. Diagnoza Spoleczna 2015. Warunki i jakość życia Polaków. http://www.diagnoza.com/pliki/raporty/Diagnoza_raport_2015.pdf [dostęp: 25.11.2016].

Czyżewski Marek. 2005. Dyskurs. W: Encyklopedia socjologii. Suplement, H. Kubiak, G. Lissowski, W. Morawski, J. Szacki (red.), 50-58. Warszawa: Komitet Socjologii PAN i Oficyna Naukowa.

Czyżewski Marek. 2008. Elementy i całość. O niektórych dylematach analizy dyskursu. W: Analiza dyskursu w socjologii i dla socjologii, Anna Horolets (red.), 19-29. Toruń: Wydawnictwo Adam Marszałek.

Dijk Teun A. van. 1993. „Principles of critical discourse analysis”. Discourse and Society, 4(2): $249-283$. 
Dijk Teun A. van. 2006. Badania nad dyskursem. W: Wspótczesne teorie socjologiczne, A. Jasińska-Kania, L.M. Nijakowski, J. Szacki, M. Ziółkowski (wybór i opracowanie), 1020-1046. Warszawa: Wydawnictwo Naukowe Scholar.

Gliński Piotr. 2006. Style działań organizacji pozarzadowych w Polsce. Grupy interesu czy pozytku publicznego? Warszawa: Wyd. ISIS PAN.

Grabowska Mirosława. (red.). 2012. Społeczeństwo obywatelskie w Polsce A.D.2012. Warszawa: CBOS.

Habermas Jürgen. 2004. Działanie komunikacyjne i detranscendentalizacja rozumu. Warszawa: Oficyna Wydawnicza.

Habermas Jürgen. 2005. Faktyczność i obowiązywanie. Warszawa: Wyd. Naukowe Scholar.

Habermas Jürgen.2007. Strukturalne przeobrażenia sfery publicznej. Warszawa: PWN.

Horolets Anna. 2008. Wprowadzenie - status dyskursu w badaniach socjologicznych. W: Analiza dyskursu w socjologii i dla socjologii, A. Horolets (red.), 5-16. Toruń: Wydawnictwo Adam Marszałek.

Kopytowska Monika, Lukasz Kumięga. 2017. Krytyczna analiza dyskursu: konteksty, problemy, kierunki rozwoju. W: Analiza dyskursu publicznego. Przeglad metod perspektyw badawczych, M. Czyżewski, M. Otrocki, T. Piekot, J. Stachowiak (red.), 177-207. Warszawa: Wydawnictwo Akademickie Sedno.

Nijakowski Lech M. 2004. „Znaczenie analizy dyskursu dla socjologii narodowej”. Kultura i Społeczeństwo, 48(1): 69-96.

Nijakowski Lech M. 2009. Analiza dyskursu na temat mniejszości narodowych i etnicznych w polskich miastach. www. racjonalista.pl/kk.php/s, 4820 [dostęp: 12.10. 2016].

Ossowska Maria. 1985. Moralność mieszczańska. Wrocław: Ossolineum.

Palska Hanna. 2007. Trwałość i zmiana stylów życia. W: Jedna Polska? Zróżnicowania społeczne, A. Kondera (red.), 159-176. Warszawa: Wyd. WAM i PAN.

Petit Phlip. 1997. Republicanism. A theory of freedom and government. Oxford: Clarendon Press.

Libelt Karol F. 1967. Samowładztwo rozumu i Objawy filozofii słowiańskiej; O miłości ojczyzny; System umnictwa; O panteizmie w filozofii. Warszawa: PWN.

Rybicki Pawel. 1979. Struktura spolecznego świata. Warszawa: PWN.

Szmatka Jacek. 1989. Małe struktury spoleczne. Warszawa: PWN.

Śnieżek Ryszard. 2001. Społeczeństwo obywatelskie w kategoriach dualizmu System /Lebenswelt w teorii krytycznej Jurgena Habermasa. W: Społeczeństwo obywatelskie, W. Bokajło, K. Dziubka (red.), 189-217. Wrocław: Wydawnictwo Uniwersytetu Wrocławskiego.

Śpiewak Paweł (red.). (2004). Komunitarianie. Wybór tekstów. Warszawa: Wydawnictwo Aletheia.

Weryński Piotr. 2008. Polskie wzory uczestnictwa w sferze publicznej. Próba typologizacji postaw na podstawie badań. W: Społeczeństwo obywatelskie. Między teorią a praktyką. A. Kościański. (red.). Warszawa: Wydawnictwo IFiS PAN.

Weryński Piotr. 2010. Wzory uczestnictwa obywatelskiego Polaków. Warszawa: Wydawnictwo Naukowe IFiS PAN.

Wnuk-Lipiński Edmund. 2008. Socjologia życia publicznego. Warszawa: Wydawnictwo Naukowe Scholar.

Zarycki Tomasz, Tomasz Warczok. 2014. „Hegemonia inteligencka: Kapitał kulturowy we współczesnym polskim polu władzy”. Kultura i społeczeństwo 58(4): 27-49.

Znaniecki Florian. 1990. Współczesne narody. Warszawa: PWN. 
Piotr Weryński

\title{
THE PUBLIC SPHERE AS PERMANENTLY CONDITIONED. CASE STUDY OF A LOCAL PUBLIC DEBATE IN MORPHOGENETIC TERMS
}

\begin{abstract}
This article analyzes the morphogenetic conditions surrounding the functioning of the public sphere at a local level, and identifies barriers to its development in Poland within the context of emergent social structures (interests) and culture (ideas, values). Such a context expresses the cultural, social, and economic dominance of one social stratum - the intelligentsia. Based on the ontological and epistemological assumptions of the theory of morphogenesis, this paper presents a case study of public discourse in Tarnowskie Góry. Qualitative field data (participant observations), elements of critical discourse analysis, and Jürgen Habermas's assumptions of the ideal speech situation are utilized.
\end{abstract}

Keywords: public sphere, participant observations, patterns of active citizenship, morphostasis, collective actions entities 